\title{
Breast Cancer pT0 TNM Finding v6 and v7
}

National Cancer Institute

\section{Source}

National Cancer Institute. Breast Cancer pTO TNM Finding v6 and v7. NCI Thesaurus.

Code C48973.

Breast cancer with no evidence of primary tumor. (from AJCC 6th and 7th Eds.) 